\title{
ZKUŠENOSTI SE ZPRACOVÁNÍM HYPERSPEKTRÁLNÍCH DAT POŘÍZENÝCH UAV
}

\author{
Lucie ČERVENÁ ${ }^{1}$, Jakub LYSÁK¹, Markéta POTU゚ČKOVÁ ${ }^{1}$, Lucie KUPKOVÁ ${ }^{1}$ \\ ${ }^{1}$ Katedra aplikované geoinformatiky a kartografie, Př́rodovědecká fakulta, Univerzita Karlova, Albertov 6 , \\ 128 43, Praha 2, Česká republika
}

(lucie.cervena, jakub.lysak, marketa.potuckova, lucie.kupkova)@natur.cuni.cz

doi: https://doi.org/10.31490/9788024843988-4

\begin{abstract}
Abstrakt
Cílem příspěvku je představit zkušenosti s pořizováním hyperspektrálních dat kamerou Headwall NanoHyperspec $\circledast$ (270 pásem v oblasti viditelného a blízkého infračerveného záření) na dronu DJI Matrice 600 Pro a jejich předzpracováním. Dưraz je kladen především na geometrické a radiometrické korekce. Data jsou pořizována za účelem monitoringu stavu a vývoje travních společenstev v oblasti krkonošské tundry.
\end{abstract}

Klíčová slova: kamera Headwall Nano-Hyperspec ${ }^{\circledR}$, geometrická korekce, radiometrická korekce, UAV, krkonošská tundra.

\begin{abstract}
The aim of the paper is to present experience with the acquisition of hyperspectral data by the Headwall NanoHyperspec $\circledast$ camera (270 bands in the visible and near infrared spectral regions) on the DJI Matrice 600 Pro drone and their preprocessing. Emphasis is put on geometric and radiometric corrections. The data are acquired for the monitoring of the status and development of grassland communities in the Krkonoše tundra region.
\end{abstract}

Keywords: Headwall Nano-Hyperspec $®$ camera, geometric correction, radiometric correction, UAV, Krkonoše tundra.

\section{PŘEDSTAVENÍ PROJEKTU A PŘíSTROJU゚}

Cílem tohoto příspěvku je představit zkušenosti s pořizováním a předzpracováním hyperspektrálních dat kamerou Headwall Nano-Hyperspec $®$ na dronu DJI Matrice 600 Pro za účelem monitoringu vegetace arktoalpínské tundry $v$ Krkonošském národním parku. Monitoring probíhá v rámci projektu Vegetace krkonošské tundry - minulost, současnost a budoucnost [1]. Sledovány jsou čtyři charakterem rozdílné lokality v okolí Luční boudy ( $50^{\circ} 44^{\prime} 3,75^{\prime \prime}$ s. š., $15^{\circ} 41^{\prime} 49,30^{\prime \prime}$ v. d.), na nichž dochází k expanzi některých druhů rostlin na úkor jiných (například kleče na úkor travních společenstev [2], trav třtiny chloupkaté [3] a bezkolence modrého [4] na úkor trávy smilky tuhé). Jedná se o plochy o rozloze príbližně $100 \times 100 \mathrm{~m}^{2}$. Každá plocha je za sezónu (od června do záŕí) snímána $4 x$. Cílem je zachytit sezónní i meziroční variabilitu vegetace a vytipovat vhodné termíny pro účely odlišení jednotlivých cílových druhů nebo společenstev a vyhodnotit, do jaké míry opakovaný sběr dat $v$ různých fenologických fázích přispěje ke zpřesnění výsledků klasifikace dat dálkového průzkumu Země (DPZ). Již dřive byl ke klasifikacím vegetace v krkonošské tundře DPZ úspěšně používán, viz např. [5, $6,7]$. Otázkou je, zda s pomocí UAV a hyperspektrální kamery Ize získat výsledky podrobnější (z hlediska druhové rozmanitosti a měřítka mapování) a přesnější ( $z$ hlediska úspěšnosti klasifikace) $v$ kontextu pořizovacích nákladů zařízení i terénních prací.

\subsection{Kamera Headwall Nano-Hyperspec $®$}

Kamera Headwall Nano-Hyperspec® je řádková kamera s šiřkou záběru 640 pixelů a ohniskem $17 \mathrm{~mm}$ (výrobce nabízí i $12 \mathrm{~mm}$ a $23 \mathrm{~mm}$ ). Snímky pořizuje na intervalu vinových délek od 398,784 nm do 1 001,84 $\mathrm{nm}$, celkem ve 270 pásmech (s pravidelným rozestupem mezi pásmy $2,24 \mathrm{~nm}$ ). Její radiometrické rozlišení je 12bit. Vybavena je 480 GB interního úložiště [8]. Napájena je z baterie ke gimbalu Ronin, na kterém je 

upevněna. Príslušenstvím kamery je IMU a GNSS prìíímač. Všechna tato zařízení jsou umístěna na dronu DJI Matrice 600 Pro (obr. 1).

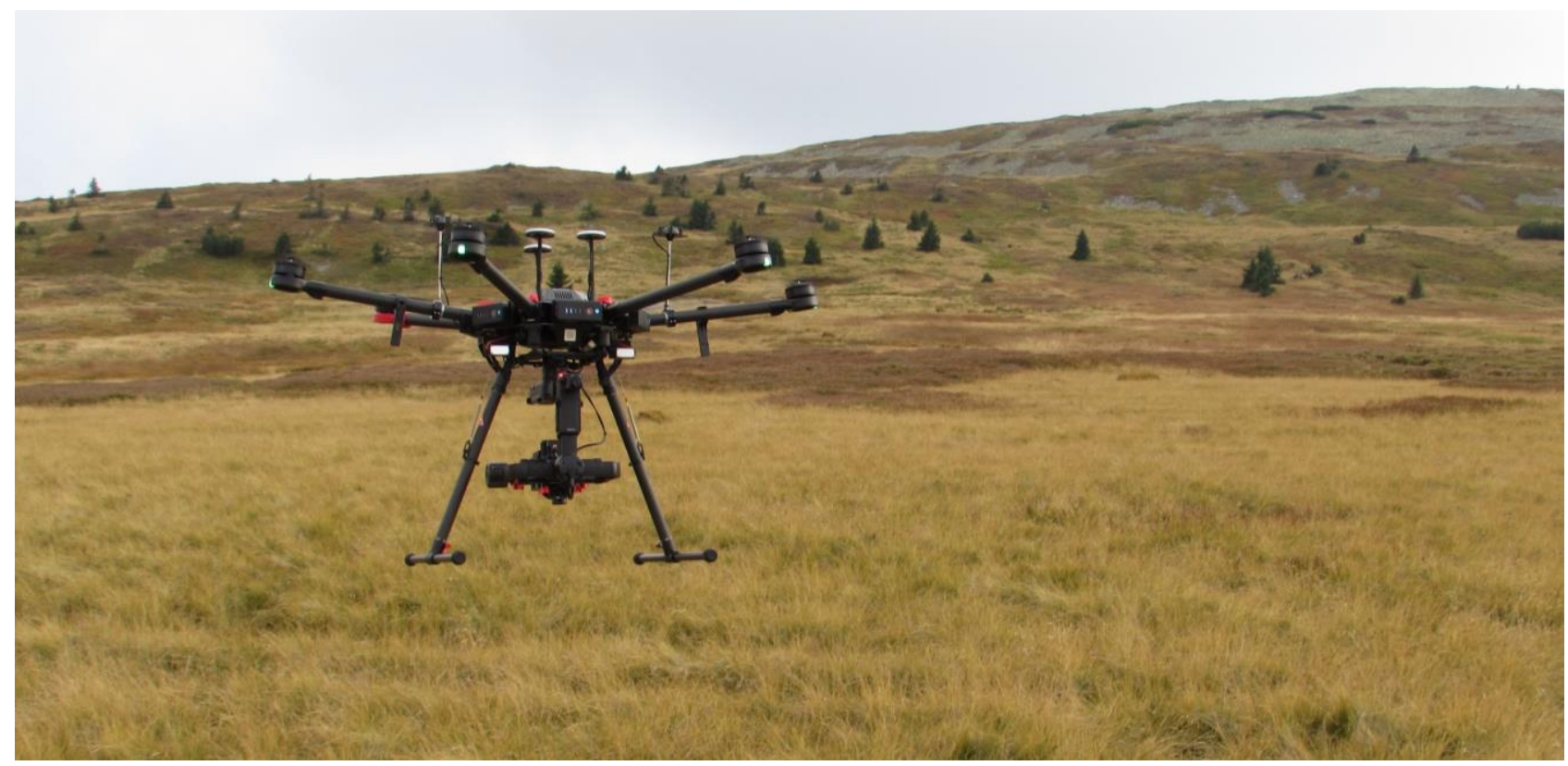

Obr. 1. DJI Matrice 600 Pro s hyperspektrální kamerou Headwall Nano-Hyperspec® před prìstáním na Bílé louce v Krkonoších

\subsection{Plánování letu a vlastní let}

K samotnému pořízení dat je potřeba práce $v$ několika softwarech. Vlastní let se plánuje $v$ softwaru Universal Ground Control Software (UgCS). Verze použivaná ke snímání v roce 2019 byla 3.3.438. Zde se nastavuje trasa letu a jeho výška v jednotlivých bodech (která může být proměnlivá), rychlost letu a další parametry, jako je např́klad typ letu dronu při přechodu mezi jednotlivými letovými liniemi a také přesah letu za hranici letového polygonu. Výsledná trasa se $\mathrm{v}$ terénu pošle do tabletu s aplikací UgCS for DJI. S pomocí této aplikace probíhá samotný let automaticky; pro účely vzletu a prisstání je z důvodů lepší kontroly chování dronu využíváno manuální ovládání pilotem. Ve webové aplikaci HPI Polygon Tool od společnosti Headwall (http://apps.headwallphotonics.com/) Ize pak vytvořený letový plán načíst a na jeho základě vytvořit textový soubor se souřadnicemi, které vymezují polygon, ve kterém má snímat kamera. Tento polygon musí být ve směru letu menší než letový polygon, napřič směru letu je lepší ho nechat naopak větší, protože ukládání dat kamery se zapne/vypne $v$ okamžiku, kdy je překročena hranice tohoto polygonu. Tento polygon pro kameru se v terénu načítá do softwaru Hyperspec III (E80220 vs.64 5.5.1 v roce 2019), kde se nastavují i parametry kamery jako je expoziční čas (exposure) a snímkovací perioda (frame period), přičemž tyto dva parametry spolu úzce souvisí. Snímkovací perioda musí být vždy větší (nebo alespoň stejná) než expoziční doba. Dále se provede kalibrace dark reference (měření vnitřního šumu přístroje) a zapíná se snímání kamery.

V rámci práce na projektu v roce 2019 probíhalo veškeré snímkování s ohledem na požadovanou výslednou velikost pixelu 0,03 m z výšky 68,9 m nad terénem. Každá letová řada je rozdělena na dvě až tři části, tzv. data cubes (2 000 řádků ve směru letu), řad pokrývající jedno zájmové území je 10 až 12 . Rychlost dronu souvisí s expozičním časem a snímkovací periodou. $V$ závislosti na světelných podmínkách byla nastavena bud' na $5 \mathrm{~m} / \mathrm{s}$ ( $v$ prípadě, že bylo slunečno) nebo $3 \mathrm{~m} / \mathrm{s}$ (zataženo).

\section{ZPRACOVÁNÍ DAT}

\subsection{Radiometrické korekce}

Pro provedení radiometrických korekcí byl využíván software SpectralView - Hyperspec v3.1.0. V prvním kroku byly všechny data cubes pro danou lokalitu a termín převedeny z DN hodnot na zář (radiance). Jediným 
vstupem do tohoto procesu je dark reference, pořizená vždy před samotným letem s parametry nastavenými stejně jako pro snímání samotných dat (stejná snímkovací perioda a expoziční čas), ale se zakrytým objektivem kamery. Druhým krokem je pak vybrání části referenčního koberce se známou $56 \%$ odrazivostí (pomocí klasifikace Spectral Angle Mapper) a uložení jeho radianční křivky jako bílé reference. Koberec se vždy nachází alespoň v jedné cube pro danou lokalitu a termín. Pomocí takto získané bílé reference jsou přepočítány všechny cubes dané lokality a termínu na odrazivost (reflectance). Problémy nastávají v prípadě nerovnoměrného osvětlení území (mraky), což způsobí nevyrovnané hodnoty naměřeného odraženého záření $v$ datech.

\subsection{Geometrické korekce}

Prvním krokem bylo sloučení cubes do jednotlivých letových řad. Toto bylo provedeno též v softwaru SpectralView - Hyperspec v3.1.0 od Headwall, kde byly cubes představující jednu letovou řadu sloučeny do mozaiky $\mathrm{s}$ využitím informací zaznamenaných $v$ průběhu letu pomocí GNSS a IMU. Dále proběhla ortorektifikace $s$ využitím $1 \mathrm{~m}$ rastrového digitálního modelu terénu, vytvořeného $z$ dat leteckého laserového skenování dodaných Správou KRNAP, pořízených $v$ roce 2012. Výstupem tohoto procesu jsou ortorektifikované letové linie, jejichž umístění v prostoru se z důvodů přesnosti GNSS a IMU ukázalo jako polohově nevyhovující, protože RMSE na testovacím bodovém poli dosahovala hodnoty 1,742 m (podrobněji viz kapitolu 3).

Bylo proto nutné další zpracování, které probíhalo v software ArcGIS for Desktop. Zahrnovalo následující kroky:

- kontrola a následná manuální úprava jednotlivých letových řad pomocí vlícovacích bodů nad ortofotem pořízeným $\mathrm{z}$ dronu ve stejném období $(+/-1$ den). $S$ ohledem na nehomogenity při výpočtu ortorektifikace $v$ softwaru SpectralView byla použita spline transformace s cca 10 identickými body/1 letovou řadu. Při zpracování nebyly úmysIně využity souřadnice vlícovacích bodů umístěných $\checkmark$ terénu, které posloužily pro kontrolu geometrických vlastností výsledného produktu (viz dále $v$ kapitole 3).

- převod 32bitových dat na 16 bitová motivovaný snížením velikosti výsledného souboru. Při tomto kroku se hodnoty odrazivosti $z$ intervalu $<0,1>$ převádějí na celočíselnou hodnotu z intervalu $<0,10000>$.

- mozaikování pásů. $S$ ohledem na snahu maximálně zachovat radiometrii nebyly hodnoty pixelů při mozaikování nijak barevně vyrovnávány a převzorkování probíhalo metodou nejbližšího souseda (nearest neighbor). $\mathrm{V}$ př́padě, že $\mathrm{v}$ průběhu snímání došlo $\mathrm{k}$ výrazné změně světelných podmínek, mohou být na výsledné mozaice jednotlivé pásy vizuálně patrné. Výsledná mozaika má velikost pixelu $3 \mathrm{~cm}$.

\section{HODNOCENÍ PŘESNOSTI PROVEDENÝCH KOREKCÍ}

\subsection{Radiometrické korekce}

Nasnímaná hyperspektrální data o šî́ce pásem 2,24 nm obsahují velké množství šumu, viz obr. 2a. Bez redukce šumu jsou data nejen velmi objemná, ale zároveň šum negativně ovlivňuje výsledky jejich zpracování. Př́kladem může být klasifikace maximální pravděpodobnosti (MLC) provedená na výřezu lokality Bílé louky (15 m × $15 \mathrm{~m}, 15.8 .2019)$, obr. 3. Testovány byly různé metody redukce pásem: analýza hlavních komponent (PCA) a metody spektrálního převzorkování. Čtyři první hlavní komponenty PCA se jeví být bez šumu a obsahují více jak 90 \% původní informace, avšak výsledky klasifikací s jejich využitím též mají určité nedostatky. Nejlepších výsledků (celková přesnost klasifikace blížící se $90 \%$ ) dosahuji spektrálně převzorkovaná data, a to na šířku pásma $11,21 \mathrm{~nm}$, kde se slučuje vždy pět sousedících pásem, celkem tedy vzniká 54 spektrálních pásem (obr. 2b, 3). Veškeré metody spektrální transformace i klasifikace byly provedeny $v$ softwaru ENVI 5.5. Klasifikace probíhaly nad totožnými trénovacími daty. 

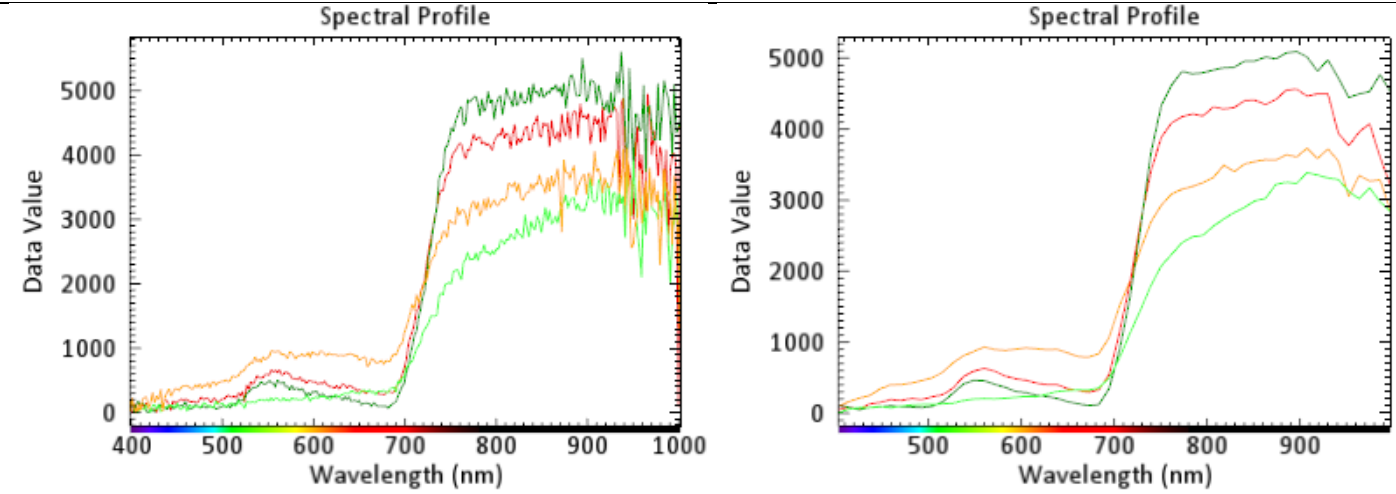

Obr. 2. Ukázka spekter a) z originální mozaiky s 270 pásmy (vlevo) a b) spektrálně převzorkované mozaiky s 54 pásmy (vpravo), legenda: oranžová - smilka tuhá, tmavě zelená - bezkolenec modrý, světle zelená třtina chloupkatá, červená - porost s ostřicí bigelowovou a dalšími druhy
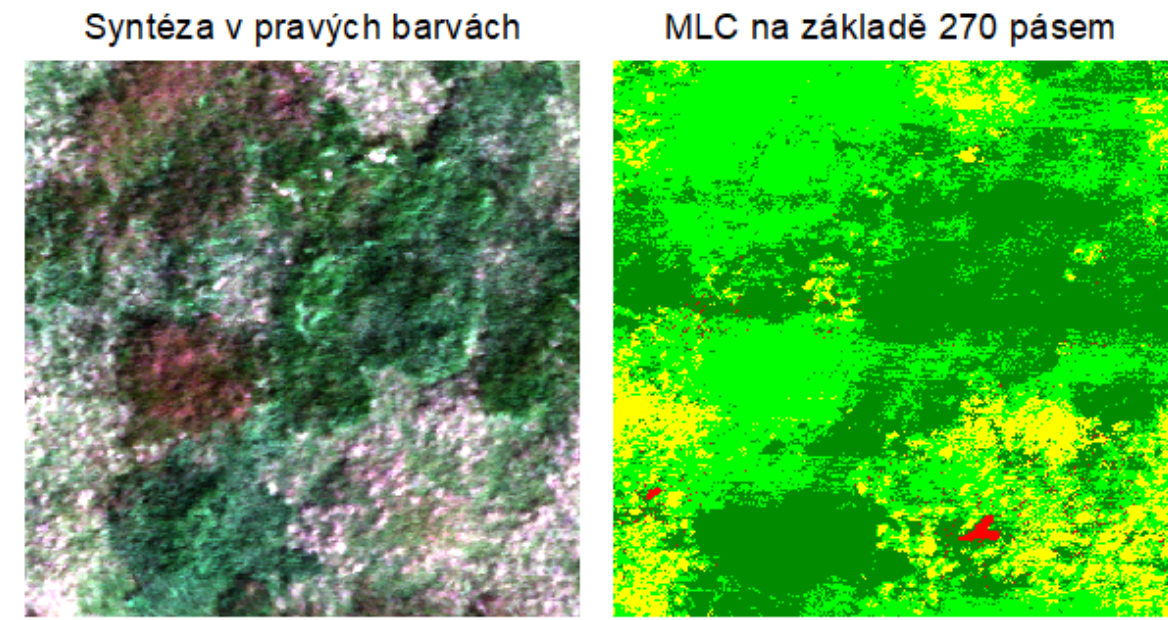

MLC na základě 54 širších pásem

\section{MLC na základě 4 pásem PCA}
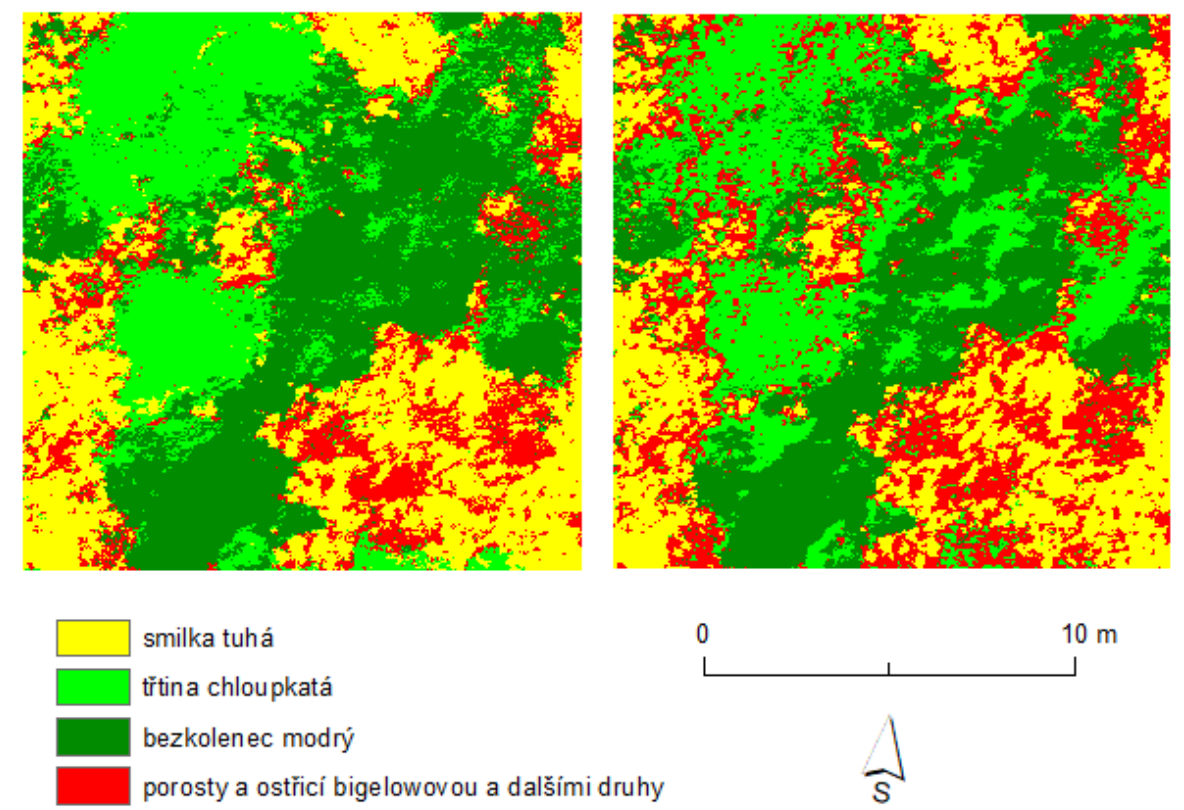

Obr. 3. Ukázka výřezu hyperspektrálních dat (15. 8. 2019) v pravých barvách a klasifikací maximální pravděpodobnosti (MLC) na základě stejných trénovacích dat s rozdílnými vstupními pásmy - originálními daty (270 pásem), spektrálně převzorkovanými daty (54 pásem) a výstupem z analýzy hlavních komponent (první 4 komponenty bez šumu) 


\subsection{Geometrické korekce}

Čtyři rohové body monitorovaných ploch a pět dalších bodů uvnitř těchto ploch bylo $v$ terénu označeno železnými trubkami, které byly zaměřeny geodetickým GNSS prístrojem (Trimble R10 LT) se střední polohovou chybou menší než $1 \mathrm{~cm}$. Před každým snímáním do nich byla vložena dřevěná kulatina $\mathrm{s}$ připevněným vycentrovaným $C D$ nastříkaným oranžovou reflexní barvou (obr. 4a). Z krajinářskoochranářských důvodů se tato signalizace bezprostředně po letu sbírá. Tyto body posloužily pro zhodnocení absolutní polohové přesnosti vytvořených hyperspektrálních mozaik. Hodnota RMSE se pohybovala mezi 8 a $13 \mathrm{~cm}$, což je o řád lepší hodnota, než poskytl přímý výstup ze softwaru SpectralView.

Pro podrobnější ověření chování polohové chyby byl v rámci snímání jedné plochy proveden experiment, při kterém bylo do celé snímané oblasti rovnoměrně rozmístěno celkem $42 \mathrm{CD}$, které byly zaměřeny geodetickým GNSS př́strojem. Následně byla určena jejich poloha ve snímcích: jak v přímém výstupu ze softwaru SpectralView, tak v konečném výstupu po manuálním zásahu (obr. 4b). Výsledná hodnota RMSE vyšla $v$ prvním prípadě $1,74 \mathrm{~m}$, po manuálním zpracování se snížila na $0,19 \mathrm{~m}$.

Z výsledných dat je rovněž vidět protažený tvar všech CD ve směru letu (zhruba $30 \mathrm{~cm}$, napríič zhruba $20 \mathrm{~cm}$, skutečný průměr $12 \mathrm{~cm}$ ), viz obr. $4 \mathrm{~b}$.
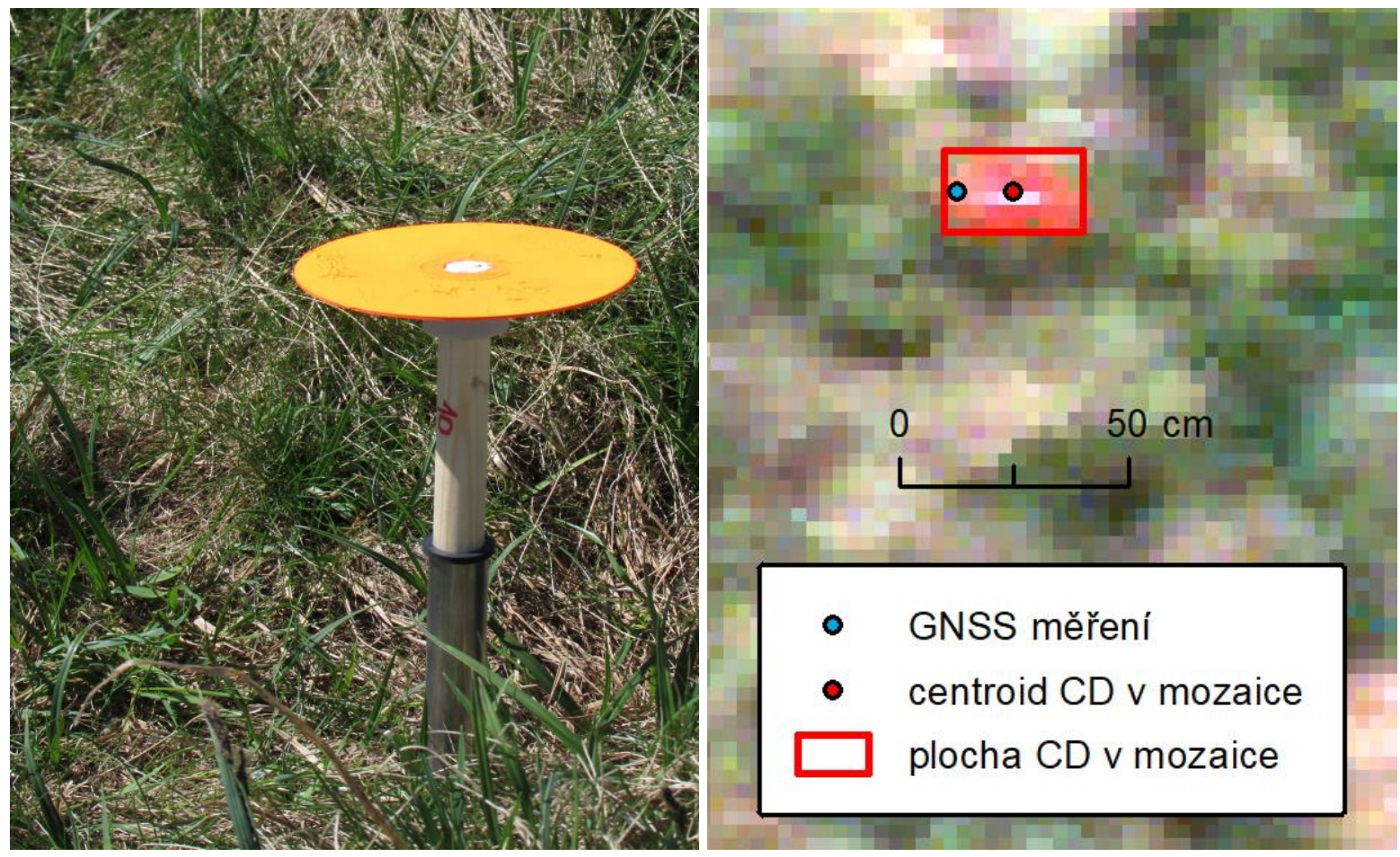

Obr. 4. a) CD zaměřené v terénu (vlevo), b) CD ve výsledné hyperspektrální mozaice (vpravo)

\section{ZÁVĚRY A DOPORUČENÍ}

Po roční zkušenosti s pořizováním dat na hřebenech Krkonoš se domníváme, že jsme schopni formulovat určitá doporučení týkající se snímání a zpracování dat v tomto území.

Hlavním problémem a jednoznačně nejvíce limitujícím faktorem vysoko na hřebenech Krkonoš je počasí. Ideální situace z hlediska pořizování hyperspektrálních dat je část bezoblačného dne, kdy je slunce vysoko na obloze a nefouká vítr. $V$ praxi tato situace nastává velmi vzácně. Velkou část doby strávené $v$ okolí Luční boudy jsme tak čekali na ideální, nebo alespoň na lepší podmínky pro snímání.

$\checkmark$ prípadě nárazů větru nad $10 \mathrm{~m} / \mathrm{s}$ je létání $s$ dronem riziko a nezbývá než čekat, až vítr ustane. $Z$ hlediska oblačnosti je pak výhodnější situace, kdy je zataženo, spiše než když se při polojasném dni střídají období s oblačností a bez oblačnosti. Stř́́dání totiž vede $\mathrm{k}$ rozdílné radiometrii u jednotlivých linií a někdy i v rámci linie, které se odstraňují velmi obtižně. Celý proces snímání navíc zdržuje kalibrace kamery před letem, díky které musí být pro úspěšné pořizení dat "okno" mezi oblaky i pro nasnímání relativně malých ploch poměrně dlouhé. 
I pokud odhlédneme od těchto krkonošských specifik, celý proces pořízení a zpracování dat je poměrně komplikovaný a nepřiliš uživatelsky přivětivý. Nutnost použivat hned několik softwarů od společnosti Headwall, $z$ nichž některé obsahují vážné chyby, $k$ přehlednosti celého procesu nepřispívá. Toto jsme vyřešili návodem o několika desítkách bodů, kterým se při pořizování dat ř́díme, aby nedošlo k chybě. Nakonec i data, která jsou výstupem softwaru, vyžadují doladění z hlediska polohové přesnosti, a ani jejich radiometrie není ideální a obsahuje velké množství šumu. Jako vhodný krok před dalším zpracováním se proto jeví snížení prostorového (převzorkování na menší velikost pixelu) i radiometrického rozlišení (zprůměrování sousedních pásem).

\section{LITERATURA}

[1] Krkonošský národní park. Vegetace krkonošské tundry - minulost, současnost a budoucnost, https://www.krnap.cz/vegetace-krkonosske-tundry/, cit. 3. 3. 2020.

[2] Štursa, Jan, and Jan Wild. 2014. "Kleč a Smilka - Klíčoví Hráči Vývoje Alpínského Bezlesí Krkonoš (Vysoké Sudety, Česká Republika)." Opera Corcontica 51: 5-36.

[3] Hejcman, Michal, Michaela Klaudisová, Pavla Hejcmanová, Vilém Pavlů, and Martina Jones. 2009. "Expansion of Calamagrostis Villosa in Sub-Alpine Nardus Stricta Grassland: Cessation of Cutting Management or High Nitrogen Deposition?" Agriculture, Ecosystems \& Environment 129 (1-3): 91-96. https://doi.org/10.1016/j.agee.2008.07.007.

[4] Hejcman, Michal, Michaela Češková, and Vilém Pavlů. 2010. "Control of Molinia Caerulea by Cutting Management on Sub-Alpine Grassland." Flora - Morphology, Distribution, Functional Ecology of Plants 205 (9): 577-82. https://doi.org/10.1016/i.flora.2010.04.019.

[5] Suchá, Renáta, Lucie Jakešová, Lucie Kupková, a Lucie Červená. 2016. „Classification of Vegetation above the Tree Line in the Krkonoše Mts. National Park Using Remote Sensing Multispectral Data". AUC GEOGRAPHICA 51 (1): 113-29. https://doi.org/10.14712/23361980.2016.10.

[6] Kupková, Lucie, Lucie Červená, Renáta Suchá, Lucie Jakešová, Bogdan Zagajewski, Stanislav Březina, a Jana Albrechtová. 2017. „Classification of Tundra Vegetation in the Krkonoše Mts. National Park Using APEX, AISA Dual and Sentinel-2A Data". European Journal of Remote Sensing 50 (1): 29-46. https://doi.org/10.1080/22797254.2017.1274573.

[7] Marcinkowska-Ochtyra, Adriana, Bogdan Zagajewski, Edwin Raczko, Adrian Ochtyra, and Anna Jarocińska. 2018. "Classification of High-Mountain Vegetation Communities within a Diverse Giant Mountains Ecosystem Using Airborne APEX Hyperspectral Imagery." Remote Sensing 10 (4): 570. https://doi.org/10.3390/rs10040570.

[8] Headwall. Nano-Hyperspec® VNIR Imaging Sensors, https://cdn2.hubspot.net/hubfs/145999/NanoHyperspec Oct19.pdf, cit. 3. 3. 2020. 